\title{
ALBANIA AND STRATEGICREFORMS IN ECONOMY AND DECENTRALIZATION OF LOCAL AUTONOMY
}

\author{
Msc (c) Florid DUMI'Prof.Dr Alba DUMI ${ }^{2}$ \\ ${ }^{1}$ Iae Lyon, France, Technique Quantitatives et Management \\ ${ }^{2}$ Dean of Graduate School'Ismail Qemali" Vlora University \\ ${ }^{1}$ Management Department , University of Tirana
}

\begin{abstract}
The main issues handled out in this presentation are: strengthening local government leadership and initiative; partnership between municipalities and NGOs; concluding all of these in the community-based approaches to infrastructure services and neighborhood revitalization.

Almost everywhere problems of water scarcity can be considerably mitigated through metering, leakage detection and reduction, network improvements, disconnection of illegal connections, and optimization of storage and supply patterns. The distribution problem in Albania also has a seasonal aspect: much more water is needed during the summer growing season; when rainfall is scarce, rural drinking water is often misused for irrigation; and the tourist resort areas use large amounts of water.
\end{abstract}

Albania is open to foreign investment and increasing FDI is a top priority for the Albanian government. Albania has put in place a liberal foreign investment regime, including a 10 percent flat corporate and income tax and has taken measures to improve the business climate by streamlining business procedures through e-government reforms. These improvements along with NATO membership and progress toward EU integration have contributed to the increase in investors' interest during the last couple of years. Promising sectors for foreign investors and include: energy (including alternative energies), telecommunications and tourism. The country's geographic position places it at the crossroads of Western and Eastern Europe. A stable U.S. ally, Albania is a member of NATO, the WTO and is in the process of applying for candidate status in the European Union.

Key words: Albanian reforms, EU process, development strategy, NATO 
General information:The concept of local autonomy, as defined in art.3 of ECLSG, is understood as the right and the ability of local authorities to regulate and manage, within the limits of law, a substantial share of public affairs under their own responsibilities and in the interest of local population. This right is exercised by local councils or assemblies, which may possess executive organs responsible to them. The notion of "ability" expresses the idea that the legal right to regulate and manage certain public affairs must be accompanied by the means of doing so effectively; meanwhile the expression "under their own responsibility" stresses that local authorities should not be limited to merely acting as agents of higher authorities. In reality most affairs have both local and national implications and responsibility for them. (Hoxhaj E)

Albania's tax system does not discriminate against foreign investors and no distinction is made between foreign and domestic investors. The e-taxes reform is progressing and as of January 2008 , corporate income tax was reduced from $20 \%$ to $10 \%$, one of the lowest in the region. In addition, as of May 2009- 2010, the social insurance contribution payable by employers will be reduced again from $20 \%$ to $15 \%$, down from $29 \%$ in 2006 . Businesses can file their tax returns and social insurance declarations electronically in 12 cities including Tirana and electronic payment of taxes is also possible through certain banks.

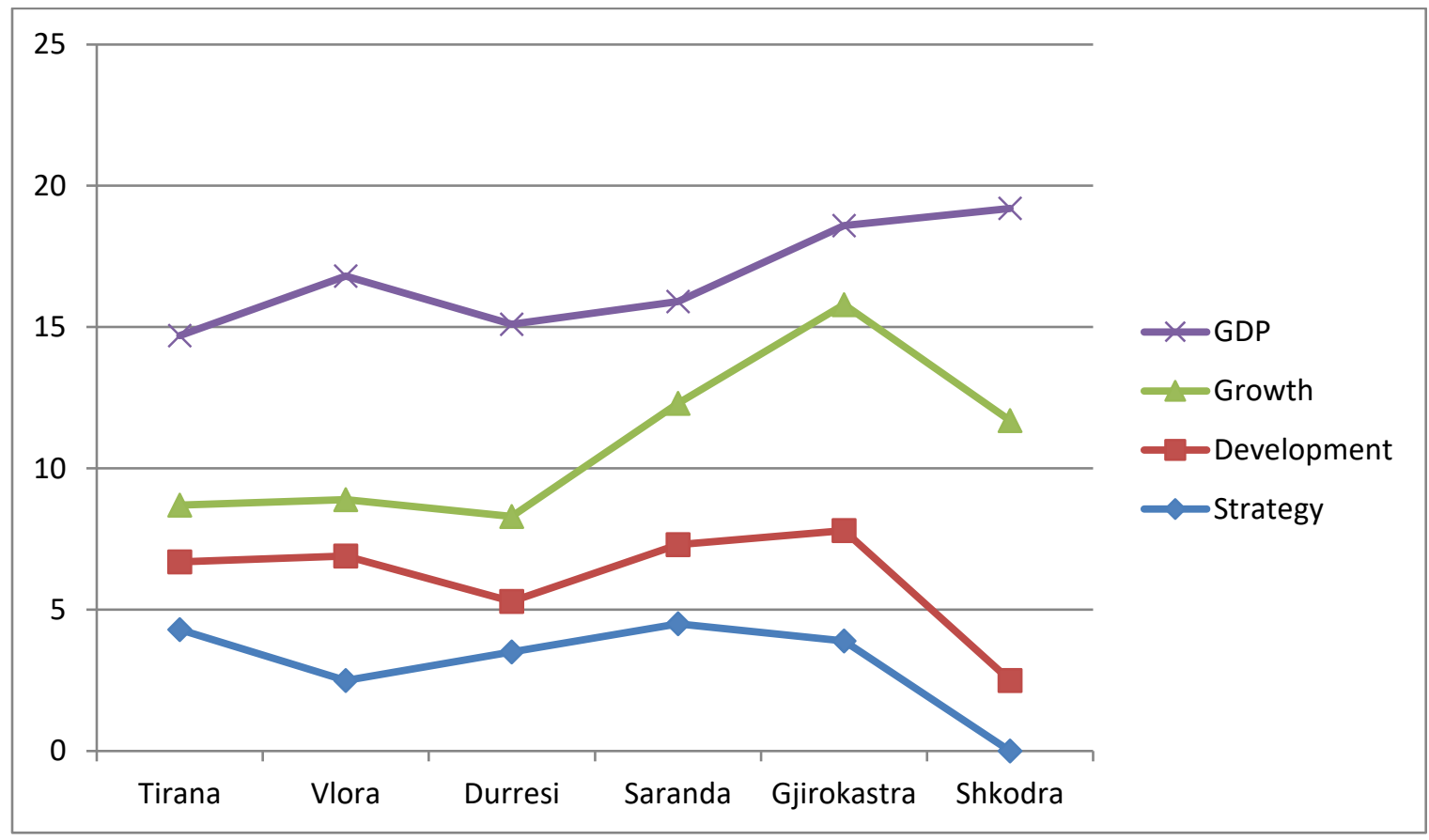

The law "On Concessions," No. 9663, dated December 18, 2006 
The mission of local government in Albania, as previewed in art.3 of the law "On the organization and functioning of local government" - which by the way is in compliance with art.4 of ECLSG, - is to provide governance at a level nearer to the citizens by means of: acknowledgment of the existence of different identities and values of the communities; respect of main citizen's human rights and liberties stated in the Constitution or other laws; choosing different sort of services and other local public facilities to the good of the community; effective exercise of functions, competences and realization of duties by the organs of local government; realization of appropriate services; effective egging of community participation in local government.(Hoxhaj E)Supported by donor assistance and international and local NGO's the city initiated a community-based development strategy in the in-formal. The program brought together local government teams, NGO's and residents to formulate a development plan for the neighborhood define priorities for improvements and determine equitable cost-sharing formulas to finance infrastructure. Source: Albanian progress reforms, 2010. This partnership led to the upgrading of roads and electrical networks, the construction of community buildings and schools, improved public spaces and programs for youthhousing.

Finally, the engagement of senior government officials in the dissemination of project information secured commitment among communities and farmers. Albania has improved public procurement by approving a new law and introducing e-procurement. The new law takes into account the principles of non-discrimination and equal treatment, transparency, and legal protection of interests of bidders on public contracts. Direct tendering has been abolished and criteria to identify abnormally low bids have been introduced. The Public Procurement Advocate was established as an independent institution reporting to parliament. However, it has no particular executive powers and its functions duplicate the monitoring tasks of the PPA.

\section{Introduction}

Many activities in Albania required cumbersome licensing procedures and permits. In 2007, the GOA approved the Action Plan for Regulatory Reform which provided for a full review of Albania's entire legal licensing system to harmonize the licensing legislation to EU standards and reduce administrative barriers for businesses operating in Albania. As a result, many licenses were removed while a broad simplification of licensing procedures has been completed in many sectors including, mining, hydrocarbons, public works, health, agriculture and the environment. By October 2008, 64 out of 151 licenses identified in 18 sectors of the economy were removed and another 21 licenses were changed into self-declaration.

Albania, one of the smallest and poorest countries in Eastern Europe, has experienced a transition marked by sharp economic swings and periods of civil strife. The early phases of decentralization witnessed the transfer of political autonomy and limited administrative and 
fiscal authority, to local governments, inadequate legislation outlining central/local responsibilities, scarce financial resources and deficient infrastructure strained the capacity of local governments to mange urban services.

In January 2000, the government promulgated a national Strategy for Decentralization and Local Autonomy which includes lows to strengthen the autonomy of local governments and increase their capacity to manage local infrastructure and services.

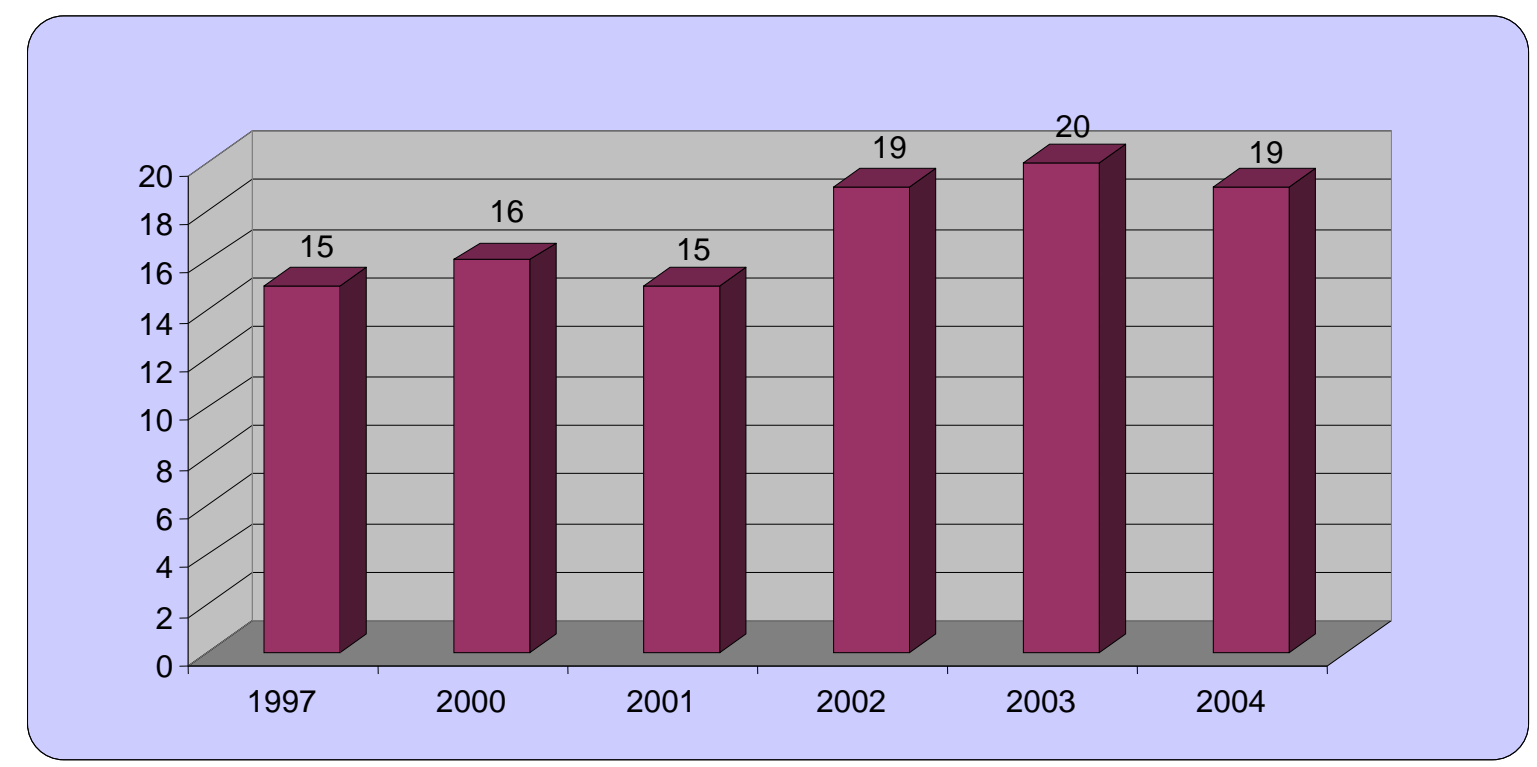

Tab1.Albania Municipal Water and Sanitation Project - Agricultural ministry project 2004

\section{STRENGTH LOCAL GOVERNMENT LEADERSHIP AND INITIATIVE}

Work is in progress to identify other licenses that could be removed. For the remaining licenses the government plans to start a "One-Stop-Shop" for licensing within the first quarter of 2009. However, licensing and post-registration processes require further simplification and the removal of licenses needs to be accompanied by a strengthening of the supervision capacities of public agencies. The procedures for getting a license are the same for national and foreign companies.

Decentralization has given local governments the discretion and scope they need to take a lead role in responding to the challenges of economic down-turn, degradation of the urban environment, and social hardship. They institute bold initiatives and innovative practices. 
Western European nations have put in place sophisticated frameworks to provide local governments with technical and financial assistance.

The European Union supplements these national programs with coordinated assistance aimed at promoting economic development, assisting distressed localities and fostering social inclusion.

The keys of success are seven key factors:

- A dynamic local government leadership

- A coherent strategy acted upon with determination

- A healthy climate of cooperation with business

- Local government's investment initiatives to jumpstart the stagnant economy

- Creative use EU funds to implement local policy

- Efficient municipal administration

- Coherent links among urban planning, infrastructure and economic development

\section{PARTNERSHIPS BETWEEN MUNICIPALITIES AND NGOS FOR PUBLIC GOALS.}

Partnerships with municipalities has provided the best channel for the participation of communities in the organized delivery of public services and paved the way for the growing role of NGO' $\mathrm{s}$ and CBO's in this sector in urban and rural areas and different regions of the world.

Supported by donor assistance and international and local NGO's the city initiated a communitybased development strategy in the informal. The program brought together local government teams, NGO's and residents to formulate a development plan for the neighborhood define priorities for improvements and determine equitable cost-sharing formulas to finance infrastructure.

This partnership led to the upgrading of roads and electrical networks, the construction of community buildings and schools, improved public spaces and programs for youth. Clarifying the legal status of residential land and formalizing an urban plan resulted in the sufficient leveraging of community and house4hold resources to provide infrastructure and build new housing. Finally, the engagement of senior government officials in the dissemination of project information secured commitment among communities and farmers.

To work closely with Community- Based organizations so as to enhance their capacity to participate in development programs and strengthen the City Council's capacity to respond to requests from communities 
- To adopt a new approach to Environmental Planning and Management based on capacity building.

The CIP upgraded infrastructure, enhanced participation and built the capacity of CBOs and stakeholders. CIP strengthened institutional capacity by establishing program offices in each community, forming steering committees made up of representatives from all stakeholder groups and formalizing institutional links between the relevant partners and information for decisionmaking and monitoring of performance among the stakeholders altered attitudes and understanding of roles and responsibilities.

\section{COMMUNITY-BASED APPROACHES TO INFRASTRUCTURE SERVICES AND IMPROVEMENT OF HEALTH SYSTEM}

\section{Expropriation and Compensation}

In the post-communist period, expropriation has been limited to land needed for infrastructure projects, such as roads and airports. Compensation has generally been below market value and some owners have complained about the slow compensation process and low payments. The restitution process of properties confiscated during the communist regime started in 1993 but is still far from complete. The process is tainted with corruption and lack of political will. Several U.S. citizens and residents have long-running disputes with the government regarding restitution for property. Many property cases end up in the courts and drag on for years without a final decision.

No requests will be accepted after the deadline. However the entire set of restitution compensation claims is not expected to be resolved before 2014. The GOA has presented three methods of compensation for expropriation claims: 1) restitution, 2) compensation of property with similarly valued land in a different location, and 3) cash settlement/financial compensation. The successful implementation of the restitution process is an important challenge for the government and is keys to future economic development.

The property registration process has been completed in approximately $86 \%$ of the country and almost entirely in rural areas. However, more lucrative land in high value urban and coastal areas has still not been registered. Many of the unregistered properties are in the south coastal area, which is more valuable for its tourism potential, and where disputes are more frequent. The main institutions dealing with property restitution and registration are the Agency for Restitution and Compensation and the Office for the Registration of Immovable Properties. 
This is a highly significant feature of infrastructure programs and carries important implications for local development.The law "On Concessions," No. 9663, dated December 18, 2006

Sustained political pressure and the demonstrated capacity of municipalities to manage their responsibilities were the driving forces for local administrative and fiscal autonomy. Initial assessments suggested that decentralization did improve the quality of service delivery and foster a new, user oriented attitude, facilitating the transition from a centrally planned to a market economy.

Decisions on appeals are taken by the same unit of the PPA that is responsible for interpreting the law and giving advice to contracting authorities. Current procedures for handling complaints still do not meet recognized international standards. Despite progress, its application is hampered by technical problems, the insufficient IT capacity of many contracting authorities and corruption in drafting tender documents. Companies continue to experience issues with transparency in specifications and communication in competing for public tenders. Overall, the improvements in the public procurement legislation are advancing while the proper enforcement of the law is still a work in progress.

The law "On Concessions," No. 9663, dated December 18, 2006, established the necessary framework for promoting and facilitating the implementation of privately financed concessionary projects enhancing transparency, fairness, efficiency and long-term sustainability in the development of infrastructure and public service projects. One of its major amendments includes a better regulation for unsolicited proposals and of public-private partnerships in general. The law applies to a wide range of sectors, including:

transport (railway system, rail transport, ports, airports, roads, tunnels, bridges, parking facilities, public transport);

b) generation and distribution of electricity and heating;

c) production and distribution of water, treatment, collection distribution and administration of waste water, irrigation, drainage, cleaning of canals, dams;

d) collection, transfer, processing and administration of solid waste;

e) telecommunication;

f) education and sport;

g) health;

h) tourism and culture;

i) prison infrastructure;

j) recycling projects, rehabilitation of land and forests, in industrial parks, housing, governmental buildings, service of maintenance of IT and data base infrastructure;

k) natural gas distribution;

1) management contracts or provision of public services including those related to sectors specified above. 
In order to promote investments in priority sectors the GOA may offer concessions to local or international investors for the symbolic price of one euro. The GOA, with the approval of the Minister of Economy, authorizes concessions in other sectors besides the ones listed above. The law does not apply to concessions that require a separate operating license unless that is included in the framework of the concession agreement. The law "On Concessions," No. 9663, dated December 18, 2006

The privatization process of the past 19 years has almost come to an end with only a few large privatizations remaining. Privatization forms include public auctions and public tenders.

Following some large privatizations which were finalized in 2009, the GOA will most likely start the procedures for the privatization of 100 percent of the state-owned insurer INSIG (following the failure of negotiations with the winner in early 2009 for the sale of 61 percent of the shares, EBRD and IFC exercised the put option for their 39 percent and GOA became the owner of 100 percent of the INSIG shares.) In addition, the GOA has announced its intention to fully privatize Alb-petrol, the state-owned company that manages and administers all the existing gas and oil fields in Albania. The company also has the right to sign petroleum agreements with interested parties for the existing gas and oil fields. In addition, the GOA will also privatize through an auction the 16 percent of state owned shares of the fixed line monopoly Alb-telecom. The law “On Concessions, ” No. 9663, dated December 18, 2006

The commune represents a territorial administrative unit by rule in rural areas and in particular cases in urban areas also; meanwhile the municipality represents a territorial administrative unit mainly in urban areas and in particular cases include also rural areas - these are the definitions given by art.5 /2,3 of the Albanian law "On the organization and functioning of local government". By them we can simply understand that the commune includes some villages; meanwhile the municipality is created principally on city base. Subdivision of the commune is the village or, in rare cases, the city; subdivision of the municipality in urban areas is the quarter, but it can be also the village when the municipality includes rural areas. According to Albanian legislation quarters are created by decision of municipality council in a territory with more than 15.000 inhabitants, and villages are created in a territory with more than 200 inhabitants (Hoxhaj E)

All partners are unlimitedly and jointly liable for the debts of the entity. Creditors can claim against a partner for the debts of the partnership, only if they have failed in their claims against the partnership as a whole. In unlimited partnerships, the partners are all considered administrators of the partnership, unless the contrary is stipulated in the bylaws. Each partner represents the partnership with third parties. An unlimited partnership should issue annual financial reports. The rights, duties and obligations of partners are governed by written bylaws, which should be filed with the National Registration Center. The law "On Concessions," No. 9663, dated December 18, 2006 


\section{Limited Partnership}

A limited partnership, which is seldom used in practice, consists of one or more general partners (unlimited) with unlimited liability and one or more limited partners whose liability is limited to the amount of their agreed contributions of the initial capital. Source: Commission of the European Communities),

A limited partner may not take part in the management of the partnership even if he is given a proxy, otherwise he incurs unlimited liability. The Articles of Incorporation of the limited partnership should contain:-

1.The total amount or value of the contributions of all partners;

2.The amount or value of the contribution made by each general or unlimited partner;

3. The percentage of the participation of all general partners and of each limited partner in the partnership's profits and in the remaining value after its dissolution.

Source: Commission of the European Communities), 1992.

\section{Limited Liability Company (LLC)}

This is the most common legal form of conducting business in Albania. Its members enjoy limited liability and, unless the articles of the bylaws provide otherwise, members have the right to transfer their shares to other persons, upon decision of three fourths of the shareholders. It can be established by one or more partners, legal or natural persons, who are responsible for losses only to the extent of their contribution to the capital of the company. The minimum required capital for this form of company is approximately \$1 USD. The capital is divided into shares and there are no mandatory requirements for their nominal value. The contributions to capital can be in cash or in any asset, tangible or intangible. The law does not permit contributions in services. Administrators nominated through the General Assembly of the shareholders manage the limited liability company. Extraordinary decisions, increases or decreases in the share capital, mergers and acquisitions are to be approved by at least three quarters of the capital shareholders. The law requires annual financial statements to be prepared by the company. The transformation of this form of business into unlimited and limited partnership is subject to decision of general assembly of the shareholders that takes valid decisions upon majority vote of $3 / 4$ of shareholders and after approval of financial statements for the last two years.Source: Commission of the European Communities),

\section{Foreign Direct Investment Statistics}

The FDI has increased although it still remains among the lowest in the region. The cumulative FDI is also the lowest in the region. The Bank of Albania reported the following figures for 
foreign direct investment in Albania. Regardless of numerous contracts, only a few projects materialized in 2009.

\begin{tabular}{|c|c|c|c|c|c|c|}
\hline Years & 2004 & 2005 & 2006 & 2007 & 2008 & $2009 *$ \\
\hline \multirow[t]{2}{*}{ FDI in million Euro } & 279 & 212 & 359 & 481 & 653 & 580 \\
\hline & $32 \%$ & $28 \%$ & $32 \%$ & $35.8 \%$ & $41 \%$ & $52 \%$ \\
\hline Profitable in million Euro & & & & & & \\
\hline
\end{tabular}

Source: Bank of Albania *A B estimate for the first three quarters of 2009

FDI during the first nine months of 2009 is estimated to have reached 580 million euro despite optimistic GOA projections for 2009 fueled mainly by strong investor interest witnessed during 2007-2008. A large part of FDI is due to privatizations. The Albanian government collected 103 million Euro from the privatization of 76 percent of the shares of the distribution arm of Albanian Power Corporation; 48 million Euro from the privatization of 12.6 percent of AMC state controlled shares; 5 million euro from the privatization of $40 \%$ of GOA controlled shares of the United Bank of Albania. INSIG (insurance company) privatization failed during the negotiation process with the winter and it might take place during 2010. \{1\} Albanian government report 2010 pg 12,25,41,58,74

Leading investor nations in Albania include: Italy, Greece, Turkey, Austria, Germany, Canada, Spain and the U.S. Foreign investment focuses on financial sector, oil and gas production, telecommunications, mining, metallurgy, energy, manufacturing production.

\section{Joint Stock Company}

Its capital is divided into shares, with shareholders held responsible for losses only to the extent of their contribution to the capital. The minimum initial capital required is ALL 2 million for companies with no public offering, and ALL 10 million for public offerings. The Commercial Law provides for the adoption by joint stock companies of a flexible administration system. This type of companies may choose to adopt either the "monistic" system (with a board of directors/administrators conducting both management and supervising functions) or the "dualistic" system (with board of directors/administrators and supervisory board conducting 
supervising functions). The supervisory council exercises control over the board of director's performance. This council should have not less than 3 and not more than 21 members.

The capital is fully subscribed when the partners have promised to bring assets to the company in cash or in kind for an amount equaling the capital. In the moment of the subscription, at least one quarter of the nominal value of the shares representing contributions in cash must be paid in. Payment of the remaining value shall be made in installments upon the decision of the management bodies of the company. Shares of contributions in kind must be fully paid in at the moment of subscribing. The law does not permit contributions in services.

In January 2000, the government promulgated a national Strategy for Decentralization and Local Autonomy which includes lows to strengthen the autonomy of local governments and increase their capacity to manage local infrastructure and services. \{1\}De Soto, Hermine; Egamberdi, Nilufar; Center for Economic and Social Studies (CESS), 2006. Supported by donor assistance and international and local NGO's the city initiated a community-based development strategy. The program brought together local government teams, NGO's and residents to formulate a development plan for the neighborhood define priorities for improvements and determine equitable cost-sharing formulas to finance infrastructure.

This partnership led to the upgrading of roads and electrical networks, the construction of community buildings and schools, improved public spaces and programs for youth. Clarifying the legal status of residential land and formalizing an urban plan resulted in the sufficient leveraging of community and house4hold resources to provide infrastructure and build new housing. Finally, the engagement of senior government officials in the dissemination of project information secured commitment among communities and farmers.

- To work closely with Community- Based organizations so as to enhance their capacity to participate in development programs and strengthen the City Council's capacity to respond to requests from communities

To adopt a new approach to Environmental Planning and Management based on capacity building. \{1\} Albania-Rural Water Supply and Sanitation Strategy 2009

The CIP upgraded infrastructure, enhanced participation and built the capacity of CBOs and stakeholders. CIP strengthened institutional capacity by establishing program offices in each community, forming steering committees made up of representatives from all stakeholder groups and formalizing institutional links between the relevant partners and information for decisionmaking and monitoring of performance among the stakeholders altered attitudes and 
ISSN 2661-2666( Online) International Scientific Journal “Monte" DOI : $\underline{10.33807 / \text { monte.1.201904227 }}$ ISSN 2661-264X (Print)

understanding of roles and responsibilities. Communities have agreed to earmark part of stakeholders, asa partner in urban development ensures, the sustainability of these assets.

\section{References}

a. Overseas Private Investment Corporation,1100 New York Ave., NW Washington,Commission of the European Communities, "Council directive of 27 June 1985 the assessment of the affects of certain public and private projects on the European Communities, L175, pages 40-48

b. " Towards sustainability-a European Community programmed of policy and actions in relation to the environment and sustainable development" COM(92)

c. 23 final- vol 11 (Commission of the European Communities), 1992.

d. Leung, Hok Lin. Land Use Planning Made Plain Ronald Fruye

e. Bradler\& Sediss ,The rapport Company: Kingston, Ontario, 1989.

f. Hydric Management : Departmentof the Environment, London 1996.

g. De Soto, Hermine; Egamberdi, Nilufar; Center for Economic and Social

h. Studies (CESS), 2006.

i. Albania: Municipal Water and Sanitation Project - Social Assessment.

j. Albanian Agricultural ministry report 2009 pg 14-18 